\title{
Berbagai Aspek Kepemimpinan Kepala Sekolah
}

\author{
Anco \\ Fakultas Ilmu Pendidikan Universitas Indraprasta, Jakarta \\ email: ancofarhama@gmail.com
}

\begin{abstract}
Abstrak
Sekolah merupakan sebuah sistem yang meliputi guru, peserta didik, tenaga kependidikan, sarana prasarana, dan lingkungan sosial. Komponnen-komponen tersebut merupakan satu kesatuan yang utuh dalam rangka pencapaian tujuan-tujuan bersama. Secara faktual, tidak jarang ditemukan komponen-komponen sekolah berjalan secara sektoral, seakan terpisahkan dari yang lain. Peran kepala sekolah sangat strategis dalam merekatkan komponen-komponen sekolah, demi pencapaian tujuan sekolah. Kemampuan kepala sekolah dalam mengelola pelanggan internal maupun eksternal menunjukkan tanggungjawab sosial yang tinggi, sekaligus upaya perbaikan mutu lembaga pendidikan.
\end{abstract}

\section{Kata Kunci: Kepemimpinan, Mutu, Tanggung Jawab Sosial}

\section{Various Principal Leadership Aspects}

\begin{abstract}
School is a system that includes teachers, students, education staff, infrastructure, and social environment. These components constitute a unified whole in the framework of achieving common goals. Factually, it is not uncommon to find school components running sectorally, as if they were separated from the others. The role of the school principal is very strategic in attaching school components to achieving school goals. The ability of principals to manage internal and external customers shows high social responsibility, as well as efforts to improve the quality of educational institutions.
\end{abstract}

Keywords: Leadership, Quality, Social Responsibility 


\section{Pendahuluan}

Menjadi kepala sekolah tidak hanya menempati posisi formal tertinggi pada struktruk organisasi sekolah. Lebih dari itu, peran-peran strategis terutama pada saat-saat krusial, menuntut untuk ditunaikan. Karenanya seorang pemimpin sekolah tidak hanya hadir secara seremonial, tetapi dituntut lebih partisipatif.

Komponen-komponen sekolah seperti guru, peserta didik, tenaga kependidikan, sarana prasarana, dan lingkungan sosial membutuhkan sentuhan positif dari kepala sekolah. Praktik keguruan yang sektoral, hanya peduli pada kegiatan pembelajaran semata, mengabaikan persoalan-persoalan sekolah lainnya, dapat menjadi petunjuk bahwa peran-peran kepala sekolah belum berjalan dengan seharusnya. Demikian pula sarana prasarana yang belum terurus sebagaimana mestinya untuk mendukung core business sekolah, dapat diduga berkaitan dengan persoalan kepemimpinan. Tenaga kependidikan yang tidak menunjukkan peningkatan kapasitas, dan hubungan masyarakat yang buruk, menguatkan asumsi kelemahan kepemimpinan sekolah.

Oleh karena itu, kepala sekolah bukanlah guru biasa. Bukan hanya lama dalam menjalani pengabdian sebagai pendidik, tetapi menjiwai relung-relung kehidupan persekolahan. Ia adalah pribadi yang memiliki kesadaran bahwa sekolah adalah benda mati tetapi dihuni oleh manusia yang sangat dinamis. Maka kepala sekolah berjalan diantara nilai-nilai kepatutan-kepatuhan dengan inovasiinovasi untuk semakin maju.

Sebagai pendidik, kepala sekolah menjalankan kepemimpinan tutwuri handayani, ing madya mangun karso, ing ngarso sung tulodo. Tidak hanya berbicara tetapi memberi contoh, secara terus menerus berada di tengah-tengah warga sekolah. Sebagai pengelola, kepala sekolah adalah sekolah pemikir tentang kondisi lingkungan saat ini dan bagaimana menempatkan sekolah di masa depan. Merumuskan pandangan tentang masa depan sekolah, merumuskan agenda-agenda penting yang harus dikerjakan, dan memastikan hasil-hasil nyata yang diharapkan. Komponen manusia dipastikan memiliki peran-peran yang jelas, karenanya berbagai pekerjaan harus dapat dikelompokkan sesuai kebutuhan. Demikian pula dalam pelaksanaan kegiatan, membutuhkan kehadiran kepala sekolah dalam memastikan bahwa desain kerja dan pelaksanaan telah dilaksanakan secara konsisten, jika perlu melakukan perbaikan-perbaikan. 


\section{Deskripsi Kepala Sekolah}

Kepala Sekolah berasal dari dua kata yaitu, "kepala" dan "Sekolah" kata kepala dapat diartikan sebagai ketua atau pemimpin dalam suatu organisasi atau sebuah lembaga. Sedang kata Sekolah adalah sebuah lembaga dimana menjadi tempat menerima dan memberi pelajaran.Jadi secara singkat kepala sekolah dapat diartikan sebagai pemimpin sekolah atau suatu lembaga dimana tempat menerima dan memberi pelajaran. ${ }^{1}$

Kepala sekolah adalah sebagai tenaga fungsional guru untuk memimpin suatu sekolah dimana diselenggarakan proses belajar mengajar, atau tempat dimana terjadi interaksi antara guru yang memberi pelajaran dan murid yang menerima pelajaran. Kepala sekolah sebagai pemimpin pendidikan memiliki tanggung jawab dalam meningkatkan pencapaian hasil belajar siswa agar menguasai aspek kognitif, afektif, dan psikomotorik dengan memerhatikan kompetensi guru, peranan kepala sekolah sebagai pemimpin pembelajaran (pendidikan) di sekolah di antaranya menjadi narasumber bagi guru, mengondisikan guru untuk mencapai cita-cita profesional tinggi, dan mengembangkan kemampuan profesionalitas guru.

Kepala sekolah sebagai manajer diharapkan bisa menerjemahkan visi, misi, dan strategi sekolah ke dalam formula yang secara strategis menjadi pedoman dalam melaksanakann seluruh aktifitas sekolah. Peran kepala sekolah dalam kaitanya dengan kinerja pembelajaran adalah mengadakan buku kurikulum bersama pedomannya; bersama guru memahami dan menjabarkan tujuan pendidikan yang meliputi tujuan umum, tujuan instruksional tujuan kurikuler, dan tujuan khusus; bersama guru menusun program kurikuler dan kegiatan tambahan lainnya, termasuk berbagai program tahunan; bersama guru mengembangkan alat dan media pembelajaran, menyusun jadwal dan pembagian tugas, mengembangkan evaluasi belajar, melakukan pengawasan terhadap kegiatan proses belajar mengajar, menyusun norma kenaikan kelas, serta mengembangkan perpustakaan sebagai ilmu dan tempat belajar.

${ }^{1}$ Anas Purwantoro, "Upaya Sekolah Dalam Meningkatkan Kedisiplinan Siswa MTSN Ngemplak, Sleman, Yogyakarta, skripsi, (Fakultas Tarbiyah Universitas Islam Negeri Sunan Kalijaga Yogyakarta, 2008), h. 10. 


\section{Motivator Tenaga Pendidik}

Kepala Sekolah diharapkan dapat memotivasi guru agar aktif bekerja menurut prosedur dan metode tertentu sehingga tugas yang diembannya terlaksana dengan efektif dan efisien. Kemampuan kepala sekolah tersebut terutama berkaitan dengan pengetahuan dan pemahaman mereka terhadap manajemen dan kepemimpinan, serta tugas yang dibebankan kepadanya. Karena tidak jarang kegagalan pendidikan dan pembelajaran di sekolah disebabkan oleh kurangnya pemahaman kepala sekolah terhadap tugas-tugas yang harus dilaksanakannya. Kondisi tersebut menunjukkan bahwa berhasil tidaknya suatu sekolah dalam mencapai tujuan serta mewujudkan visi dan misinya terletak pada bagaimana manajemen dan kepemimpinan kepala sekolah, khususnya dalam menggerakan dan memberdayakan berbagai komponen sekolah. Selain itu, kepala sekolah diharapkan dapat memotivasi guru agar aktif bekerja meurut prosedur dan metode tertentu sehingga tugas yang diembannya terlaksana dengan efektif dan efisien. Peranan memotivasi dan mengaktifkan ini disertai dengan usaha untuk menyejahterakan guru, sehingga akan memberikan hasil yang lebih optimal.

Kepala sekolah sebagai pemimpin pembelajaran diharapkan mampu meningkatkan kualitas pembelajaran melalui guru. Penekanannya adalah bagaimana kepala sekolah memberikan inspirasi kepada guru untuk mengemban tugasnya dengan kualitas yang tinggi. Kepala sekolah berperan aktif sebagai pemimpin pengajaran yang berupaya, untuk meningkatkan kinerja pemebelajaran. Kepala sekolah diharapkan mampu berperan sesuai dengan tugas, wewenang, dan tanggung jawabnya. Kepala sekolah diharapkan dapat berperan sebagai manejer dan pemimpin yang efektif. Sebagai manejer, kepala sekolah diharapkan mampu mengatur semua potensi sekolah agar dapat berfungsi secara optimal.

Hal ini dapat dilakukan jika kepala sekolah mampu melaksanakan fungsi-fungsi manajemen dengan baik, yaitu terkait dengan perencanaan, pengorganisasian, pelaksanaan, dan pengawasan. Kepala sekolah perlu merencanakan semua progran atau kegiatan yang berhubungan dengan pembelajaran dengan melibatkan warga sekolah, terutama guru, serta menentukan hasil berupa rencana tahunan sekolah yang akan berlaku pada tahun ajaran berikutnya, rencana tahunan tersebut kemudian dijabarkan kedalam program tahunan sekolah yang biasa dibagi dalam dua semester. Menurut 
Schein, program tahunan berfungsi sebgai acuan untuk membuat program semesteran dan program semesteran berfungsi sebagai acuan menyusun program satuan pelajaran/persiapan mengajar, acuan kelender kegiatan belajar mengajar untu mencapai efisien dan efektifitas penggunaan waktu belajar efektif yang tersedia. ${ }^{2}$

Kepala sekolah sebagai pemimpin pembelajaran, harus mengerti wilayah pengembangan sekolah serta dapat memberikan apa yang diinginkan siswanya, termasuk guru dan staf. Kepala sekolah harus melaksanakan kepemimpinan pembelajaran yang kuat, mengelolah program pembelajaran, memiliki harapan yang tinggi pada diri sendiri, guru, dan terhadap siswa, dan mencurahkan sebagaian besar waktunya untuk mengordinasi fisik maupun sumber daya manusia sehingga proses pembelajaran berjalan lancar dan tujuan sekolah dapat dicapai secara efektif.

\section{Pengelola Sekolah}

Kepala sekolah sebagai manajer diharapkan bisa menerjemahkan visi, misi, dan strategi sekolah ke dalam formula yang secara strategis menjadi pedoman dalam melaksanakann seluruh aktifitas sekolah. Peran kepala sekolah dalam kaitanya dengan kinerja pembelajaran adalah mengadakan buku kurikulum bersama pedomannya; bersama guru memahami dan menjabarkan tujuan pendidikan yang meliputi tujuan umum, tujuan instruksional tujuan kurikuler, dan tujuan khusus; bersama guru menyusun program kurikuler dan kegiatan tambahan lainnya, termasuk berbagai program tahunan; bersama guru mengembangkan alat dan media pembelajaran, menyusun jadwal dan pembagian tugas, mengembangkan evaluasi belajar, melakukan pengawasan terhadap kegiatan proses belajar mengajar, menyusun norma kenaikan kelas, serta mengembangkan perpustakaan sebagai ilmu dan tempat belajar.

Kepala sekolah dalam melaksanakan tugas-tugas sebagai seorang pemimpin pembelajaran. Pemimpin pembelajaran adalah pemimpin yang memfokuskan/menekankan pada pembelajaran dengan komponen-komponennya meliputi kurikulum, proses belajar mengajar, asesmen, penilaian, pengembangan guru, layanan prima dalam pembelajaran, dan pembelajaran komunitas belajar di sekolah.

${ }^{2}$ Euis Karwati dan Donni Juni Priansa., Kinerja Dan Profesionalisme Kepala Sekolah Membangun Sekolah yang Bermutu, h. 97. 
Peran memotifasi dan mengaktifkan ini disertai dengan usaha untuk menyejahterakan guru, sehingga akan memberikan hasil yang lebih optimal. Dalam kaitan ini, kepala sekolah sebagai pemimpin pembelajaran diharapkan mampu meningkatkan kualitas pembelajaran melalui guru. Penekanannya adalah bagai mana kepala sekolah memberikan inspirasi kepada guru untuk mengemban tugasnya dengan kualiatas yang tinggi. Kepala sekolah berperan aktif sebagai pemimpin pengajaran yang berupaya untuk meningkatkan kinerja pengajaran guru secara efektif, serta meningkatkan prestasi akademik peserta didik.

Berdasarkan Hasil penelitian juga ditunjukan Ainscow bahwa dalam menjalankan tugas kepemimpinan di sekolah, kepala sekolah memilki sejumlah peranan yang harus di emban, antara lain; Manajer, Pemimpin instruksional (pembelajaran), Penegak disiplin, Fasilitator humas, Evaluator, Mediator konflik. Proses yang tak jauh bebeda terjadi dan berlangsung pula dimasyarakat yang sudah maju (Moderen) ${ }^{3}$.

Para orang tua memberikan perhatian terhadap pendidikan putra-putri, generasi muda masyarakatnya. Tujuan dan misi pendidikan yang dilaksanakan, pada prinsipnya sama, yaitu memberi bimbingan agar dapa hidup mandiri. Bimbingan diberikan pleh generasi tua (orangtua atau guru) kepada generasi muda (putra-putri atau peserta didik), agar dapat meneruskan dan melestarikan tradisi yang hidup di masyarakat. Tenaga pendidikan dan kependidikan dalam proses pendidikan memegang peranan strategis terutama dalam upaya membentuk watak bangsa melalui pengembangan kepribadian dan nilai-nilai diinginkan. Dipandang dari dimensi pembelajaran, peranan pendidik (Guru, dosen, pamong belajar, instruktur, tutor, widyaiswara) dalam masyarakat indonesia tetap dominan sekalipun teknologi yang dapat dimanfaatkan dalam proses pembelajaran berkembang amat cepat.

Hal ini disebabkan karena adanya dimensi-dimensi proses pendidikan, atau lebih khusus lagi proses pembelajaran, yang di perankan oleh pendidik yang tidak dapat digantikan oleh teknologi. Fungsi mereka tidak akan bisa seluruhnya dihilangkan sebagai pendidik dan pengajar bagi peserta didiknya. Begitupun dengan

3 Ainscow, Mel, Tony Booth, and Alan Dyson. Improving schools, developing inclusion. Routledge, 2006. 
tenaga kependidikan (Kepala sekolah, pengawas, tenaga perpustakaan, tenaga administrasi) mereka bertugas melaksanakan administrasi, pengelolaan, pengembangan, pengawasan, dan pelayan teknis untuk menunjang proses pendidikan pada satuan pendidikan.

\section{Menjadi Leader}

Banyak orang berharap diri mereka menjadi pemimpin. Namun mereka sering kali tak menyadari bahwa sebenarnya mereka adalah pemimpin bagi diri mereka sendiri. Ketika seorang mengenal siapa diri dan tuhannya, ia telah memiliki pegangan/prinsip hidup yang kokoh dan jelas, sehinggga tidak mudah terpengaruh oleh lingkungannya yang terus berubah dengan cepat. Ia memiliki prinsip yang bersumber dari dalam diri dan terpancar keluar, bukan prinsip dari luar yang yang terus berubah dan ia mampu mengendalikan pikiranya sendiri ketika berhadapandengan situasi yang sangat menekankan dan ia juga mampu mengambil keputusan yang bijaksana dengan menyelaraskan prinsipnya dan kondisi lingkungannya. Kepala sekolah harus melaksanakan kepemimpinan pembelajaran yang kuat, mengelola program pembelajaran, memiliki harapan yang tinggi pada diri sendiri, guru, staf, dan terhadap siswa, dan mencurahkan sebagian besar waktunya untuk mengkoordinasi fisik maupun sumber daya manusianya sehingga proses pembelajaran berjalan lancar dan tujuan sekolah dapat tercapai secara efektif.

Kepemimpinan pendidikan merupakan kemampuan seorang pemimpin dalam memengaruhi komponen-komponen sekolah agar dapat bekerja dalam mencapai tujuan besama. Seorang pemimpin dalam lingkup pendidikan tiada lain adalah kepala sekolah. ${ }^{4}$

Kepala sekolah merupakan pimpinan tunggal di sekolah yang mempunyai tanggung jawab dan wewenang untuk megatur, mengelolah, dan menyelenggarakan kegiatan disekolah, agar apa yang menjadi tujuan sekolah dapat tercapai. Kepala sekolah merupakan salah satu komponen pendidikan yang paling berperan dalam meningkatkan kualitas pendidikan, sebagai mana dikemukakan dalam pasal 12 ayat 1 PP 28 tahun 1990 bahwa kepala sekolah bertanggung jawab atas penyelenggaraan kegiatan pendidikan, administrasi sekolah, pembinaan tenaga kependidikan lainya, dan pendayagunaan serta pemeliharaan sarana dan prasarana.

\footnotetext{
${ }^{4}$ Andang.Manajemen \& Kepemimpinan Kepala Sekolah, h. 168-178.
} 


\section{Ragam Orientasi Kepala Sekolah}

Sebuah organisasi membutuhkan seorang pemimpin untuk mengordinasi semua kegiatan agar tujuannya bisa tercapai. Pemimpin ibarat kepala dari tubuh manusia, kepala berisi otak yang mengendalikan semua kegiatan dari bagian tubuh yang lain. Bagian tubuh bagaikan bawahan yang melaksanakan perintah atau arahan dari kepala. Pemimpin juga dibutuhkan untuk mewakili anggota atau kelompok pada suatau waktu, selain itu pemimpin juga sebagai penerima resiko jika anggotanya mengalami kesulitan.Semua oerganisasi ataupun kelompok memerlukan sosok pemimpin, dapat dilihat dari komponen terkecil dari masyarakat adalah sebuah keluarga. Keluarga juga memerlukan sosok seorang pemimpin untuk membina rumah tangga yang baik. Sehingga organisasi yang besar tentunya sangat memerlukan seorang pemimpin.

Setiap anggota tentunya mendapatkan pengaruh yang berbedabeda karena pada dasarnya setiap orang memiliki cara pandang yang berbeda:

1. Task oriented leadership, yakni gaya kepemimpinan yang berorientasi tinggi pada tugas, dan rendah pada hubungan manusia.

2. Relationship oriented leadership, yakni gaya kepemimpinan yang berorientasi tinggi pada hubungan manusia, tetapi rendah pada tugas.

3. Integrated leadership, yakni gaya kepemimpinan yang beroirientasi tinggi pada tugas dan hubungan manusia.

4. Impoverished leadership, yakni gaya kepemimpinan yang berorientasi rendah pada tugas dan hubungan manusia ${ }^{5}$.

Kepemimpinan yang efektif adalah kepemimpinan yang bisa menyesuaikan dengan kondisi dan situasi organisasi. Model lainnya adalah kepemimpinan transformasional dimana seorang individu mempengaruhi sekelompok individu untuk mencapai suatu tujuan. Untuk menjadi seorang pemimpin yang efektif, seorang kepala sekolah harus dapat mempengaruhi seluruh warga sekolah yang dipimpinnya melalui cara-cara yang positif untuk mencapai tujuan pendidikan di sekolah. Kepemimpinan transformasional berfungsi merubah dan mentransformasikan individu agar mau berubah dan meningkatkan dirinya, yang didalamnya melibatkan motif dan

5 Sim, Quah Cheng. "Instructional leadership among principals of secondary schools in Malaysia." Educational Research 2, no. 12 (2011): 1784-1800. 
pemenuhan kebutuhan serta penghargaan terhadap para bawahan. Terdapat empat faktor untuk menuju kepemimpinan tranformasional, yang dikenal sebutan 4I, yaitu:

1. Idealized influence: kepala sekolah merupakan sosok ideal yang dapat dijadikan sebagai panutan bagi guru dan karyawannya, dipercaya, dihormati dan mampu mengambil keputusan yang terbaik untuk kepentingan sekolah.

2. Inspirational motivation: kepala sekolah dapat memotivasi seluruh guru dan karyawannnya untuk memiliki komitmen terhadap visi organisasi dan mendukung semangat team dalam mencapai tujuantujuan pendidikan di sekolah.

3. Intellectual Stimulation: kepala sekolah dapat menumbuhkan kreativitas dan inovasi di kalangan guru dan stafnya dengan mengembangkan pemikiran kritis dan pemecahan masalah untuk menjadikan sekolah ke arah yang lebih baik.

4. Individual consideration: kepala sekolah dapat bertindak sebagai pelatih dan penasihat bagi guru dan stafnya ${ }^{6}$.

Model berikutnya adalah pemimpin lassez faire yang memberikan kebebasan kepada personil untuk menentukan sendiri kebijaksanaan dalam melaksanakan tugas, tidak ada pengawasan dan sedikit sekali memberikan pengarahan. Kepemimpinan Laissez Faire tidak dapat diterapkan secara resmi di lembaga pendidikan, kepemimpinan laissez faire dapat mengakibatkan kegiatan yang dilakuakn tidak terarah, perwujudan kerja simpang siur, wewenang dan tanggungjawab tidak jelas, yang akhirnya apa yang menjadi tujuan pendidikan tidak tercapai. ${ }^{7}$

\section{Peran Kepala Sekolah}

Kepemimpinan kepala sekolah diartikan sebagai kemampuan dan keterampilan seseorang yang menduduki jabatan sebagai pimpinan satuan kerja untuk mempengaruhi perilaku orang lain, terutama bawahannya untuk berfikir danbertindak sedemikian rupa

${ }^{6}$ Tondok, Marselius Sampe, and Rita Andarika. "Hubungan antara persepsi gaya kepemimpinan transformasional dan transaksional dengan kepuasan kerja karyawan." Psyche 1, no. 1 (2004): 35-48.

${ }^{7}$ Kemendiknas, 2007.Peraturan Manteri Pendidikan Nasional Nomor 13 Tahun 2017 tentang Standar Kepala Sekolah.Jakarta Kementerian Pendidikan Nasional. 
sehingga melalui perilaku yang positif. Ia memberikan sumbangan nyata dalam pencapaian tujuan sekolah.

Peran pemimpin dapat diartikan sebagai seperangkat perilaku yang diharapkan dilakukan oleh seseorang sesuai dengan kedudukannya sebagai pemimpin. Covey membagi peran pemimpin menjadi tiga bagian, yaitu:

a. Path finding (pencarian alur); peran untuk menentukan visi dan misi yang pasti

b. Aligning (penyelaras); peran untuk memastikan bahwa struktur, sistem dan proses operasional organisasi memberikan dukungan pada pencapaiaan visi dan misi.

c. Empowering (pemberdaya); peran untuk menggerakkan semangat dalam diri orang-orang dalam mengungkapkan bakat, kecerdikan dan kreatifitas laten untukmampu mengerjakan apa pun dan konsisten dengan prinsip-prinsip yang disepakati ${ }^{8}$.

Faktor penting yang besar pengaruhnya terhadap mutu pendidikan adalah kepala sekolah sebagai pemimpin pendidikan. Kepala sekolah merupakan pimpinan tunggal disekolah yang mempunyai tanggung jawab untuk mengajar dan mempengaruhi semua pihak yang terlibat dalam kegiatan pendidikan di sekolah untuk bekerja sama dalam mencapai tujuan sekolah. ${ }^{9}$

Dalam hal ini dapat dilihat bahwa seorang kepala sekolah adalah yang berperan penting dalam pengelolaan setiap kegiatan di sekolah. Titik tolak proses manajemen adalah menentukan "Objectives" atau tujuan-tujuan organsasi. "Objectives" direncanakan untuk memberikan kepada suatu organisasi dan anggota-anggotanya arah dan maksud. Sehingga dalam organisasi tersebut tujuan-tujuan itu dapat digunakan sebagai suatu ukuran keberhasilan atau kegagalan. Dalam manajemen modern seorang pemimpin juga harus berperan sebagai pengelola. Dilihat dari fungsi-fungsi manajemen, yakni planning (perencanaan), organizing (pengorganisasian), dan controlling (pengawasan), maka kepala sekolah harus berperan pula sebagai supervisor. Kepala Sekolah merupakan personel sekolah yang

${ }^{8}$ Sari, Novi Mega. "KONSEP PEMBENTUKAN KARAKTER: STUDI KOMPARASI PEMIKIRAN STEPHEN R. COVEY DAN KH. IMAM ZARKASYI." PhD diss., UIN Sunan Ampel Surabaya, 2013.

9 Mulyasa, Manajemen dan Kepemimpinan Kepala Sekolah (Cet. III; Jakarta: Bumi Aksara, 2013), h. 181. 
bertanggung jawab terhadap seluruh kegiatan pendidikan dalam lingkungan sekolah yang dipimpinnya dengan dasar pancasila dan bertujuan untuk:

a. Meningkatkan ketakwaan terhadap Tuhan Yang Maha Esa;

b. Meningkatkan kecerdasan dan keterampilan.

\section{Pengelola Sarana dan Prasarana}

Pengelolaan merupakan terjemahan dari kata management, karena adanya perkembangan dalam Bahasa Indonesia, maka istilah management tersebut menjadi manajemen. Dalam Kamus Besar Bahasa Indonesia bahwa pengelolaan adalah:

a. proses, cara, perbuatan mengelola

b. proses melakukan kegiatan tertentu dengan menggerakkan tenaga orang lain.

c. prosesmembantu merumuskan kebijaksanaan dan tujuan organisasi.

d. proses yang memberikan pengawasan pada semua hal yang terlibat dalam pelaksanaan kebijaksanaan dan pencapaian tujuan.

Pengelolaan ini meliputi banyak kegiatan dan bersama-sama menghasilkan suatu hasil akhir yang berguna untuk pencapaian tujuan. ${ }^{10}$ Pengertian lebih rinci diungkapkan Sutjipto, pengelolaan pendidikan atau manajemen sarana pendidikan itu merupakan keseluruhan proses perencanaan, pengadaan, pendayagnaan dan pengawasan peralatan yang digunakan untuk menunjang tercapainya tujuan pendidikan yang telah ditetapkan. Pengertian pengelolaan adalah substantifa dari penyusunan data, merencana, mengorganisasikan, melaksanakan sampai dengan pengawasan dan penilaian.

Dijelaskan selanjutnya pengelolaan menghasilkan sesuatu yang merupakan penyempurna dari peningkatan pengelolaan selanjutnya. Kemudian menurut Suharsimi Arikunto juga mengemukakan bahwa pengelolaan sarana sering disebut sebagai administrasi materil atau administrasi peralatan, yaitu segenap proses penataan yang bersangkut paut dengan pengadaan, pendayagunaan dan pengelolaan sarana pendidikan agar tercapai tujuan yang telah ditetapkan. Berdasarkan

${ }^{10}$ Ferry Dwi Hidayanto, “ Pengelolaan Sarana dan Prasarana Pendidikan Sekolah Menengah Pertama Negeri Se-Kecamatan Pengasih Kabupaten Kulon Progo" , Skripsi (Yogyakarta: Fak. Ilmu Pendidikan Universitas Negeri Yogyakarta, 2011), h. 21 
pendapat di atas dapat disimpulkan bahwa pengelolaan sarana pendidikan adalah suatu kemampuan untuk merencanakan, mengadakan, menyimpan, atau memelihara, menggunakan sumber daya pendidikan serta penghapusan yang berupa alat pembelajaran, alat peraga, dan media pendidikan di sekolah untuk mencapai tujuan pendidikan yag telah ditetapkan secara efektif dan efisien.

Sarana pendidikan adalah semua perangkat peralatan, bahan, dan prabot yang secara langsung digunakan dalam proses pendidikan di sekolah. ${ }^{11}$ Dalam hubungan sarana pendidikan, mengklasifikasikannya menjadi beberapa macam sarana pendidikan, yaitu ditinjau dari sudut:

(1) habis tidaknya dipakai;

(2) bergerak tidaknya pada saat digunakan; dan

(3) hubungannya dengan proses belajar mengajar.

Habis tidaknya dipakai Apabila dilihat dari habis tidaknya dipakai, ada dua macam sarana pendidikan, yaitu sarana pendidikan yang habis dipakai dan sarana pendidikan tahan lama. Sarana pendidikan yang habis dipakai Sarana yang habis dipakai adalah segala bahan atau alat yang apabila digunakan bisa habis dalam waktu yang relative singkat. Sebagai contohnya adalah kapur tulis yang biasa digunakan oleh guru dan siswa dalam pembelajaran, beberapa bahan kimia yang sering kali digunakan oleh seorang guru dan siswa dalam pembelajaran Ilmu Pengetahuan Alam. Semua contoh di atas merupakan sarana yang digunakan habis pakai. Sarana pendidikan yang tahan lama Sarana pendidikan yang tahan lama adalah keseluruhan bahan atau alat yang dapat digunakan secara terus menerus dalam waktu yang relatif lama. Beberapa contohnya adalah bangku sekolah, mesin tulis, atlas, globe, dan beberapa peralatan olahraga.

Sarana pendidikan yang bergerak Sarana pendidikan yang bergerak adalah sarana pendidikan yang bisa digerakkan atau dipindahkan sesuai dengan kebutuhan pemakaiannya. Lemari arsip sekolah misalnya, merupakan salah satu sarana pendidikan yang bisa digerakkan atau dipindahkan kemana-mana bila diinginkan. Demikian pula bangku sekolah termasuk sarana pendidikan yang bisa digerakkan atau dipindahkan kemana saja.

11 Bafadal, Manajemen Perlengkapan Sekolah(Cet. III; Jakarta: Bumi Aksara, 2008), h. 2 
Sarana pendidikan yang tidak bisa bergerak Sarana pendidikan yang tidak bisa bergerak adalah semua sarana pendidikan yang tidak bisa atau relatif sangat sulit untuk dipindahkan. Misalnya saja suatu sekolah yang telah memiliki saluran dari Perusahaan Daerah Air Minum (PDAM). Semua peralatan yang berkaitan dengan itu, seperti pipanya, relatif tidak mudah untuk dipindahkan ke tempat-tempat tertentu

Ditinjau dari Hubungannya dengan Proses Belajar Mengajar Dalam hubungannya dengan proses belajar mengajar, ada dua jenis sarana pendidikan. Pertama, sarana pendidikan yang secara langsung digunakan dalam proses belajar mengajar. Sebagai contohnya adalah kapur tulis, atlas, dan sarana pendidikan lainnya yang digunakan guru dalam mengajar. Kedua, sarana pendidikan yang secara tidak langsung berhubungan dengan proses belajar mengajar, seperti lemari arsip di kantor sekolah merupakan sarana pendidikan yang tidak secara langsung digunakan oleh guru dalam proses belajar mengajar.

Secara etimologis prasarana berarti alat tidak langsung untuk mencapai tujuan. Dalam pendidikan misalnya: lokasi/tempat, bangunan sekolah, lapangan olahraga, uang dan sebagainya. ${ }^{12}$ Prasarana pendidikan di sekolah bisa diklasifikasikan menjadi dua macam. Pertama, prasarana pendidikan yang secara langsung digunkan untuk proses pembelajaran, ruang perpustakaan, ruang praktik keterampilan, dan ruang laboratorium. Kedua, prasarana sekolah yang keberadaannya tidak digunakan untuk proses belajar mengajar, tapi secara langsung sangat menunjang terjadinya proses nbelajar mengajar. Beberapa contoh tentang prasarana sekolah jenis terakhir tersebut di antaranya adalah ruang kantor, kantin sekolah, tanah dan jalan menuju sekolah, kamar kecil, ruang usaha kesehatan sekolah, ruang guru, ruang Kepala Sekolah, dan tempat parkir kendaraan.Sebagai administrator kepala sekolah harus mampu menguasai tugas-tugasnya dan melaksanakan tugasnya dengan baik.Untuk itu kepala sekolah harus kreatif mampu memiliki ide-ide dan inisiatif yang menunjang perkembangan sekolah. Berbagai tugas yang harus dilakukan kepala sekolah antara lain membuat perencanaan yaitu perencanaan yang perlu dilakukan oleh kepala sekolah, diantaranya adalah menyusun program tahunan sekolah, yang 2014), h. 51.

12 Daryanto,Administrasi Pendidikan (Cet. VIII; Jakarta: Rineka Cipta, 
mencakup program pengajaran, kesiswaan, kepegawaian, keuangan, dan penyediaan fasilitas-fasilitas yang diperlukan. Perencanaan ini selanjutnya dituangkan dalam rencana tahunan sekolah yang dijabarkan dalam dua program semester.

\section{Menjadi Administrator}

Kepala sekolah sebagai administrator sangat diperlukan karena kegiatan di sekolah tidak terlepas dari pengelolaan administrasi yang bersifat pencatatan dan pendokumentasian seluruh program sekolah.Kepala sekolah dituntut memahami dan mengelola kurikulum, administrasi peserta didik, administrasi sarana dan prasarana, dan administrasi kearsipan. Kegiatan tersebut perlu dilakukan secara efektif agar administrasi sekolah dapat tertata dan terlaksana dengan baik.

Kemampuan kepala sekolah sebagai administrator harus diwujudkan dalam penyusunan kelengkapan data administrasi pembelajaran, bimbingan dan konseling, kegiatan praktikum, kegiatan di perpustakaan, data administrasi peserta didik, guru, pegawai TU, penjaga sekolah, teknisi dan pustakawan, kegiatan ekstrakurikuler, data administrasi hubungan sekolah dengan orang tua murid, data administrasi gedung dan ruang dan surat menyurat. Kepala sekolah dalam perannya sebagai administrator dalam hal ini juga berkenaan dengan keuangan, bahwa untuk tercapainya peningkatan kompetensi guru tidak lepas dari faktor biaya.

Seberapa besar sekolah dapat mengalokasikan anggaran peningkatan kompetensi guru tentunya akan mempengaruhi terhadap tingkat kompetensi para gurunya. Masalah keuangan adalah masalah yang peka.Oleh karena itu dalam mengelola bidang ini kepala sekolah harus hati-hati, jujur dan terbuka agar tidak timbul kecurigaan baik dari staf maupun dari masyarakat atau orang tua murid.

Salah satu tugas utama Kepala Sekolah dalam administrasian sarana pengajaran ialah bersama-sama dengan staf menyusun daftar kebutuhan mereka akan alat-alat sarana tersebut dan mempersiapkan perkiraan tahunan untuk diusahakan penyediaannya. Kemudian menyimpan dan memelihara serta mendistribusikan kepada guru-guru yang bersangkutan, dan menginventarisasi alat-alat atau sarana tersebut pada akhir tahun pelajaran. Maksudnya dalam hal ini adalah:

1. Mempersiapkan perkiraan tahunan Biasanya Kepala Sekolah membuatdaftar alat-alat yang diperlukan di sekolahnya sesuai 
dengan kebutuhannya dengan daftar alat yang distandarisasi.Sedangkan untuk alat-alat yang belum distandarisasi, kepala sekolah sama-sama menyusun kebutuhan sekolah masingmasing.

2. Menyimpan dan mendistribusikan.

Ada beberapa prinsip administrasi penyimpanan peralatan dan perlengkapan pengajaran sekolah.

a. Semua alat-alat dan perlengkapan harus disimpan di tempat-tempat yang bebas dari faktor-faktor perusak seperti: panas lembab, lapuk, dan serangga.

b. Harus mudah dikerjakan baik untuk menyimpan maupun yang keluar.

c. Mudah didapat bila sewaktu-waktu diperlukan.

d. Semua penyimpanan harus diadministrasikan menurut ketentuan bahwa persediaan lama harus lebih dulu dipergunakan.

e. Harus diadakan inventarisasi secara berkala.

f. Tanggung jawab untuk pelaksanaan yang tepat secara terperinci dan dipahami dengan jelas oleh semua pihak yang berkepentingan. $^{13}$

Pendistribusian peralatan dan perlengkapan pengajaran ini harus berada dalam tanggung jawabsalah seorang anggota staf yang ditunjuk.Karena pelaksanaan tanggung jawab ini hanya bersifat ketatausahaan maka kurang tepat jika Kepala Sekolah atau guru sendiri yang langsung melaksanakannya. Yang paling tepat adalah pegawai tata usaha. Kebijaksanaan pendistribusian ini hendaklah ditekankan kepada prinsip efisien dan fleksibelitas, maksudnya bila diperlukan sewaktu-waktu segera dapat disediakan.

Administrasi Perawatan walaupun pelaksanaan administrasi peralatan dan perlengkapan sudah merupakan pekerjaan rutin orangorang dihadapkan kesukaran-kesukaran yang kurang berarti, namun untuk penyempurnaan pekerjaan tersebut para ahli menyarankan beberapa pedoman pelaksanaan administrasinya. Diantaranya adalah :

a. Hendaknya Kepala Sekolah tidak terlalu menyibukkan dirinya secara langsug dengan urusan pelaksanaan administrasi peralatan dan perlengkapan pengajaran.

13 Bafadal, Manajemen Perlengkapan Sekolah (Cet. III; Jakarta: Bumi Aksara, 2008), h. 6 
b. Melakukansistem pencatatan yang tepat sehingga mudah dikerjakan.

c. Administrasi peralatan dan perlengkapan pengajaran harus senantiasa ditinjau dari segi pelayanan untuk turut memperlancar pelaksanaan program pengajaran.

d. Kondisi-kondisi di atas akan terpenuhi jika administrator mengikutsertakan semua guru dalam perencanaan seleksi, distribusi dan penggunaan serta pengawasan peralatan dan perlengkapan pengajaran yang semuanya mendorong mereka untuk memikirkan proses paling tepat dalam melayani kebutuhan-kebutuhan mereka.

Administrasi gedung dan perlengkapan sekolah Sebagai administrator, Kepala Sekolah mempunyai peranan dalam perencanaan bangunan sekolah dan perlengkapannya. Seperti halnya: Perluasan bangunan yang sudah ada, meningkatkan mutu keindahan ruang belajar, memilih prabot dan perlengkapan atau prsarana yang dibutuhkan, tanggung jawab keberesan sekolah, memperhatikan kondisi sanitasi, pemeriksaan, penyimpanan alat-alat, mengatur dan memelihara ruang belajar, memelihara halaman dan tempat bermain. Peranan Kepala Sekolah dalam perluasan bangunan yang sudah ada maksudnya disini adalah pada bangunan sekolah seudah ada sering kali diperlukan tambahan-tambahan bangunan dan perlengkapannya. Dalam masa kerjanya Kepala Sekolah ketika ingin melakukan perencanaan-perencanaan yang demikian perlu adanya kerja sama dengan guru-guru dan orang tua peserta didik untuk mengetahui penambahan-penambahan dan perombakan-perombakan bangunan yang sudah ada dan ikut serta dalam mmberikan saran-saran atau rekomendasi yang tepat dan masuk akal, dalam perencanaan bangunan yang akan dilakukan.

Dalam hal meningkatkan keindahan ruang belajar, dibutuhkan kejelian dan keahlian pada para pendidik dalam hal ini guru untuk memberikan penataan ruang yang sesuai, untuk pelaksanaan pembelajaran nantinya, diamana ruang kelas harusdicat dan ruang yang tertata rapi agar peserta didik merasa nyaman dalam melakukan proses pembelajaran di ruang kelas. Memilih prabot dan perlengkapan, kepala sekolah hendaknya serba bisa, karena bukan hanya handal mengenai bangunan namun juga dalam pemilihan peralatan dan perlengkapan ruang kelas yang harus disediakan, memeriksa keadaaan sarana dan prasarana yang ada dan pemeliharaannya. 


\section{Kesimpulan}

Perkembangan persekolahan kekinian menuntut upaya-upaya tingkat tinggi pemberdayaan berbagai asset sekolah, material maupun spritual. Keberadaan kepala sekolah dalam kondisi demikian tidak lagi bersifat formalistik, tetapi hadir secara nyata membawa perubahan. Para guru yang memainkan peran-peran fungsional, harus menyadari bahwa mereka adalah pemilik tanggung jawab masa depan menjadi kepala sekolah. Karenanya mereka semestinya membelajarkan diri untuk tidak berpikir sektoral, hanya mengurus pembelajaran an sich, tetapi terus-menerus memahami berbagai persoalan sekolah. Hal ini dapat menjadi modal dasar ketika mendapatkan amanah sebagai pemimpin sekolah di masa depan. 


\section{Daftar Pustaka}

Ainscow, Mel, Tony Booth, and Alan Dyson. Improving schools, developing inclusion. Routledge, 2006.

Andang, M. Pd. "Manajemen \&Kepemimpinan Kepala Sekolah." (2013).

Bafadal, Manajemen Perlengkapan Sekolah (Cet. III; Jakarta: Bumi Aksara, 2008)

Daryanto, Administrasi Pendidikan (Cet. VIII; Jakarta: Rineka Cipta, 2014)

Euis, Karwati, and Donni Juni Priansa. "Kinerja dan Profesionalisme Kepala Sekolah Membangun Sekolah yang Bermutu." (2013).

Hidayanto, Ferry Dwi, " Pengelolaan Sarana dan Prasarana Pendidikan Sekolah Menengah Pertama Negeri Se-Kecamatan Pengasih Kabupaten Kulon Progo", Skripsi (Yogyakarta: Fak. Ilmu Pendidikan Universitas Negeri Yogyakarta, 2011)

Kemendiknas, 2007.Peraturan Manteri Pendidikan Nasional Nomor 13 Tahun 2017 tentang Standar Kepala Sekolah.Jakarta Kementerian Pendidikan Nasional.

Mulyasa, Manajemen dan Kepemimpinan Kepala Sekolah (Cet. III; Jakarta: Bumi Aksara, 2013)

Purwantoro, Anas, "Upaya Sekolah Dalam Meningkatkan Kedisiplinan Siswa MTSN Ngemplak, Sleman, Yogyakarta, skripsi, (Fakultas Tarbiyah Universitas Islam Negeri Sunan Kalijaga Yogyakarta, 2008)

Sari, Novi Mega. "KONSEP PEMBENTUKAN KARAKTER: STUDI KOMPARASI PEMIKIRAN STEPHEN R. COVEY DAN KH. IMAM ZARKASYI." PhD diss., UIN Sunan Ampel Surabaya, 2013.

Sim, Quah Cheng. "Instructional leadership among principals of secondary schools in Malaysia." Educational Research 2, no. $12(2011)$

Tondok, Marselius Sampe, and Rita Andarika. "Hubungan antara persepsi gaya kepemimpinan transformasional dan transaksional dengan kepuasan kerja karyawan." Psyche 1, no. 1 (2004) 